\title{
USING WEB-BASED TOOLS TO ACHIEVE ENVIRONMENTAL COMPLIANCE IN THE ARCHIPELAGO OF PUERTO RICO
}

\author{
JAVIER VELEZ-AROCHO ${ }^{1}$, TOBY J. DAVIS ${ }^{2}$, TY GARMON ${ }^{2}$ \& JAVIER MERCADO-BARRERA ${ }^{1}$ \\ ${ }^{1}$ EcoStahlia Consultores Ambientales, USA \\ ${ }^{2}$ LJA Engineering Inc., USA
}

\begin{abstract}
The implementation of the United States Environmental Protection Agency's National Pollutant Discharge Elimination System - Municipal Separate Storm Sewer Systems, or NPDES - MS4 permits, represents a real challenge to cities around the United States of America and its territories. Such is the case in the Commonwealth of Puerto Rico, which is undergoing a serious financial crisis in most of its municipalities due to industrial, economic, and tax-related transformations. This crisis, along with rigorous environmental laws and regulations at the federal level, require municipal governments to prioritize where to invest their limited funding for the improvement of their jurisdiction's environmental quality. In addition, the intrinsic natural, economic and social characteristics of this US territory in the Caribbean make the enforcement of the NPDES-MS4 program extremely challenging. The allocation of both human and economic resources to comply with the regulations requires new approaches and strategies, as is integrating technology and web-based tools for a more efficient use of time as well as financial accountability. The use of technological devices and programs is critical to advance in the implementation of compliance programs. Easily operated software or equipment proves to be effective in helping municipalities to strengthen their local enforcement ordinances, which are a key element for the success of the NPDES-MS4. Since 2015, we have identified and categorized over 1,000 illegal discharges in twelve municipalities. Integrating modern tools, such as the web-based permit managers, has provided municipalities with a much-needed capability to address efficiently some of the environmental issues we face now a day. The flexibility offered by the new technology has proven very effective helping municipalities to establish a robust data management strategy aimed to implement their environmental permits while saving thousands of dollars on inspection costs.

Keywords: NPDES - MS4, MS4Web, technology, environmental compliance, water quality, stormwater regulations, Puerto Rico.
\end{abstract}

\section{INTRODUCTION}

The United States Environmental Protection Agency (US EPA) established 44 years ago the National Pollutant Discharge Elimination System under the existing Clean Water Act of 1972 to protect and restore the chemical, physical, and biological integrity of the US water resources. In November 1990, the US EPA issued final regulations requiring National Pollutant Discharge Elimination System Permits (NPDES) for stormwater discharges from municipal separate storm sewer systems and industrial activities. Later in 1999, the US EPA established regulations requiring that Small MS4s be regulated pursuant to an NPDES permit [1]. The regulations also specified six minimum control measures including Public Education and Outreach, Public Participation/Involvement, Illicit Discharge Detection and Elimination, Construction Site Runoff Control, Post-Construction Site Run-off, and Pollution Prevention/Good Housekeeping that were to be included in the permits. As adopted in 2003, the first generation permit contained the six control measures although in very broad terms. The permit required the Permittees to develop stormwater management plans (SWMPs) with time frames for accomplishing the tasks described. Most of the federal regulations enforced in Puerto Rico were made for the US Mainland, where most of the states have the economic 
resources needed for their implementation, and where well-planned cities and counties are the norms. Like many states and cities in the US, the Commonwealth of Puerto Rico has many programs, laws, and regulations delegated by the federal government to address complex environmental issues. The NPDES-MS4 is one of several regulations delegated by the US EPA to local governments [2]. These set of rules although unique in its requirements, present a challenge to small cities and counties due to the similarity with local laws and regulations like the ones existing in Puerto Rico. Many local governments and state agencies struggle to differentiate the overlapping of the law and regulations, making it very difficult to comply with specific requirements [3].

\section{AN OVERVIEW OF THE ENVIRONMENTAL REGULATIONS IN THE COMMONWEALTH OF PUERTO RICO}

The Commonwealth of Puerto Rico is a US territory located approximately 990 miles southwest of Miami, Florida. The archipelago shares a legal framework with several of the US regulatory agencies such as the US Environmental Protection Agency, the US Fish and Wildlife Service, NOAA's National Marine Fisheries Services, and the US Army Corps of Engineers. At the state level, all environmental regulations are distributed between the Puerto Rico Environmental Quality Board, the Puerto Rico Department of Natural and Environmental Resources, the Puerto Rico Planning Board, and the Commonwealth's Office of Permit Management. Roughly the size of the State of Connecticut, approximately 3.7 million people live in the San Juan Metropolitan Area (San Juan, Caguas, Carolina, Bayamón, Guaynabo, Toa Baja and Cataño) and the rest of the cities and municipalities including the islands of Vieques and Culebra. A few municipalities with administrative structure capabilities manage their own permits and environmental regulations but most depend on the state and federal government to implement their regulations [4].

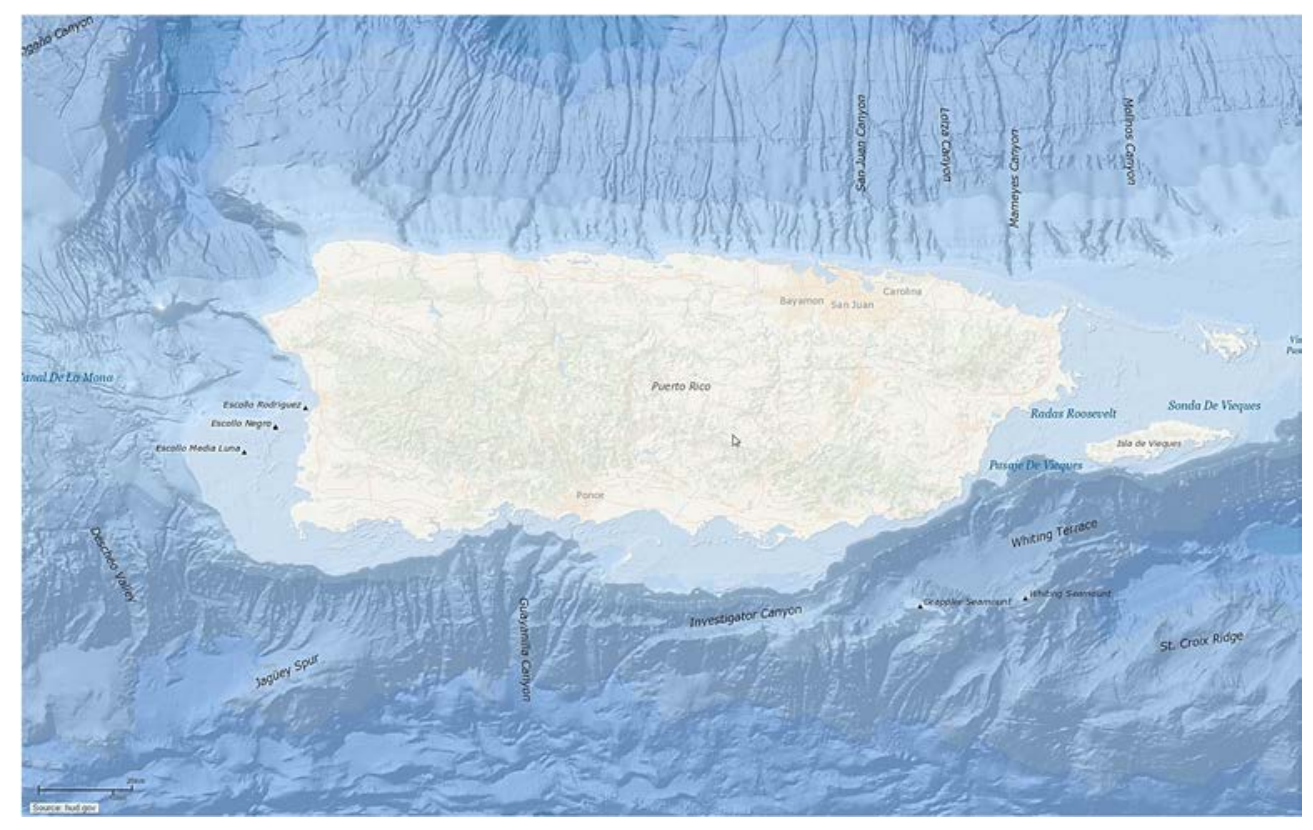

Figure 1: The archipelago of Puerto Rico general location map. 
Puerto Rico (PR) is the fourth largest island in the Caribbean West Indies $(3,475$ sq. mi., 8,897 sq. km.), and the most eastward of the Greater Antilles. Its population in 2010 was approximately 3.7 million, with a population density of 382 persons per $\mathrm{km} 2,(1,088$ persons/mi.2), one of the highest of Latin America and of the developing world. The island maintains a political relationship with the United States officially known as the Commonwealth of Puerto Rico: Estado Libre Asociado de Puerto Rico [5].

As in many cities and small municipalities in the Archipelago of Puerto Rico, the identification, assessment and the restoration of environmental issues are considered a real challenge to their administrators. The local government depends mostly on insufficient human resources and limited technological capabilities to implement the laws and regulations. The search for new techniques to deal with these problems was considered a high priority for the regulated community.

\section{INTERNET WEB-BASED TOOLS, THE EMERGING TECHNOLOGIES}

The United States Office of Management and Budget (OMB) provides procedures and guidance to implement the Government Paperwork Elimination Act (GPEA). GPEA required Federal agencies, by October 21, 2003, to allow individuals or entities to submit information or transactions with the agency electronically, when practicable, and to maintain records electronically, when practicable. For the past ten years, there have been countless of efforts aimed to minimize the use of paper in daily transactions, in both the government and private sector. Some of the reasons are to minimize the impact to the environment or to save economic resources by developing new tools that can be reached thru the Internet.

As public awareness of electronic communications and Internet usage increased, demand for online interactions between the federal and state regulators, the local governments and the common citizen also increased. Moving to electronic transactions and electronic signatures reduce transaction costs for the agency and the regulated community. Transactions are quicker and information access can be more easily tailored to the specific questions that need to be answered. As a result, data analysis is easier. These access and data analysis benefits often have a positive spillover effect on the rest of the agency as awareness of the agency's operations are improved. In addition, re-engineering the work process associated with the transaction around the new electronic format gave rise to other efficiencies [6]. As years passed, the use of the Internet reached new frontiers. These changes also included not only new and easy to navigate browsers, but also new electronic equipment made their debut in the world markets. The use of new and powerful digital processors has allowed the development of tablets, smartphones, and apps with great capabilities. The natural evolutive path was the design of web-based tools to take advantage of the new and powerful devices. Every week new applications and Internet tools are being developed to facilitate daily activities in all economic sectors, which include the environmental compliance programs.

\section{THE TRANSITION FROM PAPER TO ELECTRONIC FILES IN PUERTO RICO}

As the economic situation stroke, the Island and new regulations were developed, managers from state and municipal governments began searching for new and innovative approaches to attain the requirements. Many municipal administrations looked for off the shelf products like Microsoft Excel ${ }^{\circledR}$, PDF $^{\circledR}$ and Word ${ }^{\circledR}$ software to create tables and documents that allow them to organize data in a format to save time and money. However, these tools have limited capabilities in the field in part for the way the software's were developed. Most of these programs were meant to be used in an office environment. A new interface was needed in order to help with data collection in the field. For the past 20 years, most of the inspections in the field were carried out using paper forms made with the table formats and outlines 
available in the most popular computer programs. Inspectors had to bring a weatherproof aluminum box clipboard and a camera to complete the task; in addition to bringing loads of paper and materials to the field, which made the tasks ahead complicated. The complexity of the inspections and the fact that the technician was carrying too much equipment made these activities time-consuming and expensive, as companies needed more than one technician to complete the job. However, with the advent of the portable devices, such as, laptops, smartphones, and tablets, a new window of opportunities was opened to finally start filling the gap of flexible computer interphases that could help do the job in the field. The user interface, or UI, is the means by which a person interacts with a software or electronic device. The goal of this interaction is to allow an easily operated experience to control the device with minimal effort, whilst the machine simultaneously feeds back information that aids the operators' decision-making process. The use of interphases to address field inspections begun more than 10 years ago; today, web development tools allow developers to work with a variety of web technologies, including HTML, CSS, the DOM, JavaScript, and other components that are handled by the web browser [7].

In Puerto Rico, the use of web-based tools begun around 2004 with the need of a more agile government with a new statute called Law 151 from June 22 of 2004. The first major effort by the state government was the development of the "Puerto Rico Interactivo", a webbased platform that provides access to the general public of the data available in many of the state regulatory agencies [8]. This big step was a key element in moving the services provided by the state into the 21 st century but proved to be a great challenge for small governments. Shortly after that, in 2006 the USEPA issued the NPDES-MS4 Permit requiring the municipalities and other organizations to classify, report and document all their activities associated with the regulation. Many of the local governments faced the daunting task of complying with all their inspection requisites and keeping their records well organized due in part to their limited organizational capabilities and lack of financial resources (personal communications). In Puerto Rico, cities with a population greater than 50,000 residents have the administrative and technical infrastructure to successfully maintain and implement the regulations established under the federal legal framework. These cities have human and financial resources to conduct the necessary inspections and record keeping. Up to this point, small and large cities depended on multiple field technicians and a variety of equipment to do the job, turning the implementation into a very expensive activity.

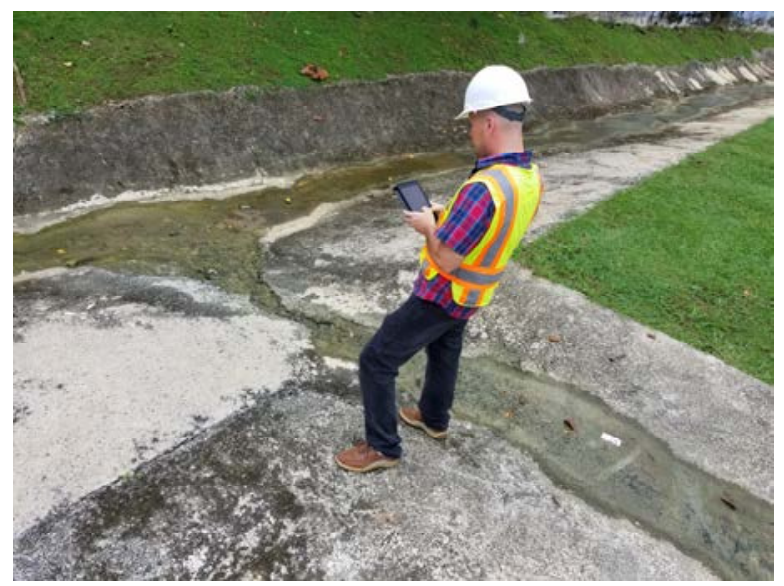

Figure 2: Inspection of an outfall from a local storm sewer with tablet device on left hand. 
For most common inspections to identify illegal discharges or to conduct an outfall inventory, it was necessary to have between 2 and 3 technicians to carry a considerable amount of equipment including cameras, GPS, and the inspection forms. All these variables served as a fertile ground for new ideas to emerge in the search for affordable and flexible solutions to address the new and more complex environmental regulations.

In 2010, the first versions of the Internet browsers specifically designed to conduct inspections using a mobile device as a way to substitute the paper forms made their debut in the applications' market [8]. As new and more powerful electronic devices like smartphones and tablets were developed, the software companies improved their products with more affordable, user-friendly and versatile versions. Many mobile communication companies started to develop hardware to substitute the use of standalone devices like the GPS and digital cameras. Most of the electronic devices available today in the market have very accurate GPS apps and High Definition (HD) cameras; likewise, the price has decreased substantially in the last ten years.

The first apps in cell phones were designed to send text messages, to play with simple arcade games or ring editors. The direct access of these units to the Internet did not work as expected. By the late 1990s, professional Websites were full color and loaded with text, images, and other types of media. They relied on JavaScript and Flash to enhance the user experience and were often designed at $800 \times 600$ pixels. Early phones had very small monochrome low-resolution screens and limited storage and processing power. They couldn't handle the data-intensive operations required by traditional Web browsers. The bandwidth requirements for data transmission were also costly to the user. The answer from the telecommunications companies was the WAP or Wireless Application Protocol. The WAP solution was great for handset manufacturers. They could write one WAP browser to ship with the handset and rely on developers to come up with the content users wanted. However, this system was very limited too. Writing graphics-intensive video game applications with WAP was nearly impossible. A variety of different proprietary platforms emerged and developers are still actively creating applications for them. One of the first was the Palm OS (now Garnet OS) and RIM Blackberry OS. Sun Microsystems popular Java platform became Java Micro Edition (Java ME). Qualcomm developed its Binary Runtime Environment for Wireless (BREW). Nokia, Sony Ericsson, Motorola, and Samsung developed Symbian OS. The Apple iPhone iOS joined the ranks in 2007. Google's Android came along a year later. Not only the price and versatility of the electronic device improved over the years but also the cost and coverage of the data plans offered by the communications companies. Once a service with a very limited coverage range, the cell phone service evolved into a powerful network of antennas and satellites all over the World [9].

After the price market was conquered by the competition between communication companies around the world, the move to replace the employee workforce was a natural step as potential clients were looking for more efficient and cost-effective alternatives.

\section{THE WEB PERMIT MANAGER TOOLS AND THE ECONOMICS OF AN INSPECTION PROGRAM}

For many years the standard procedure to conduct an inspection, to develop a database with field data followed a multi-task event. The specialist would create electronic forms, and a database on a desktop computer, then it required the site visit to obtain the necessary data. Once the data was collected, the specialist took the data back to the office to manually added into the database. This activity was time-consuming multiplying the number of hours required to gather the data, conduct the analysis and to prepare the report. The new systems, however, allowed the specialist to spend a minimal amount of time to prepare the custom list 


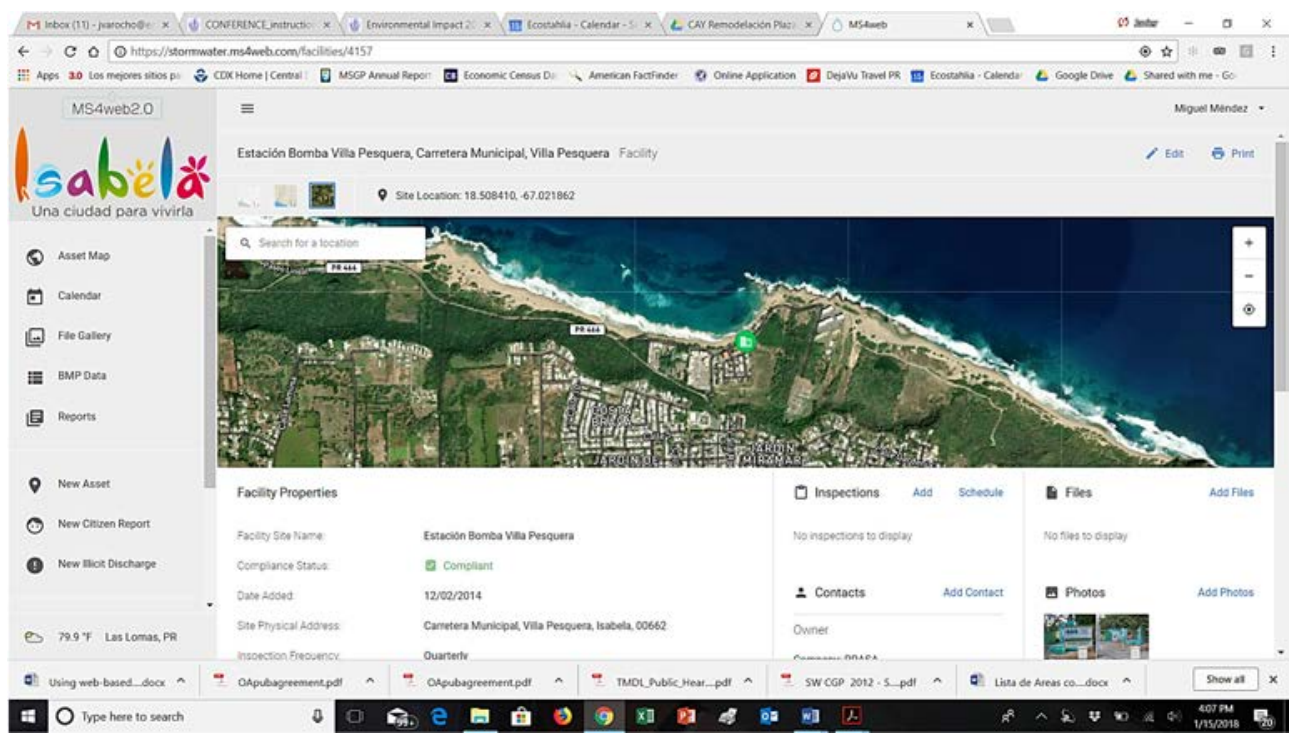

Figure 3: Image of a screenshot from the MS4Web ${ }^{\text {TM }}$ Interphase showing an outfall and several monitoring points.

of variables using a preformatted template. This mechanism allows the creation of the form list using drawdown menus and keywords, saving effort and time. Two systems available in the market, the MS4Front ${ }^{\circledR}$ and the MS4Web ${ }^{\mathrm{TM}}$, are able to interact with the different operating systems in the market, and the interphases are designed to run on $\mathrm{MacOS}^{\circledR}$ $\left(\right.$ Unix $\left.^{\circledR}\right)$, Android $^{\circledR}\left(\right.$ Linux $\left.^{\circledR}\right)$ and Windows ${ }^{\circledR}$. The data used by the tools can be managed in ArcGIS, PDF and Excel formats; and they are known as web-based interfaces. Their developers built these applications to collect data during field inspections allowing the users to access permit information in real-time from any location, log inspections and maintenance activities in the field for outfalls screenings, illicit discharges, construction sites, municipal facilities, structural BMPs, non-structural BMPs and industrial and commercial facilities. With the use of remote servers and cloud services, the mobile applications automatically synchronize the collected data with the user's database. Like many products of this kind, they have differences on how the display the information, the level of detail, and the data they track compared to each database. One example is that the MS4Front ${ }^{\mathbb{B}}$ tracks pollutant load reductions associated with the total maximum daily load (TMDL) waste load allocations, while the MS4 $\mathrm{Web}^{\mathrm{TM}}$ has a powerful GIS feature to track the status of the Best Management Practices implemented by the user.

In the MS4Web ${ }^{\circledR}$, the system offers user profile and safety features to protect the data from unwanted access [10], [11]. However, the system is designed to allow the general public to access specific areas of the client profile. The benefits of using this new format versus the use of paper forms include Access to data from the regulatory agencies, the general public if required, easier audit procedures as data exist in one place and under one standard procedure, access to location data, reports and photos using drawdown menus.

According to the Director of the Office of Environmental Affairs in the Municipality of Caguas, Mr. Guillermo Rivera, PL, the average cost of an inspection conducted by a Full Time Employee (FTE) in the municipal government is approximately $\$ 554.00$ dollars, 


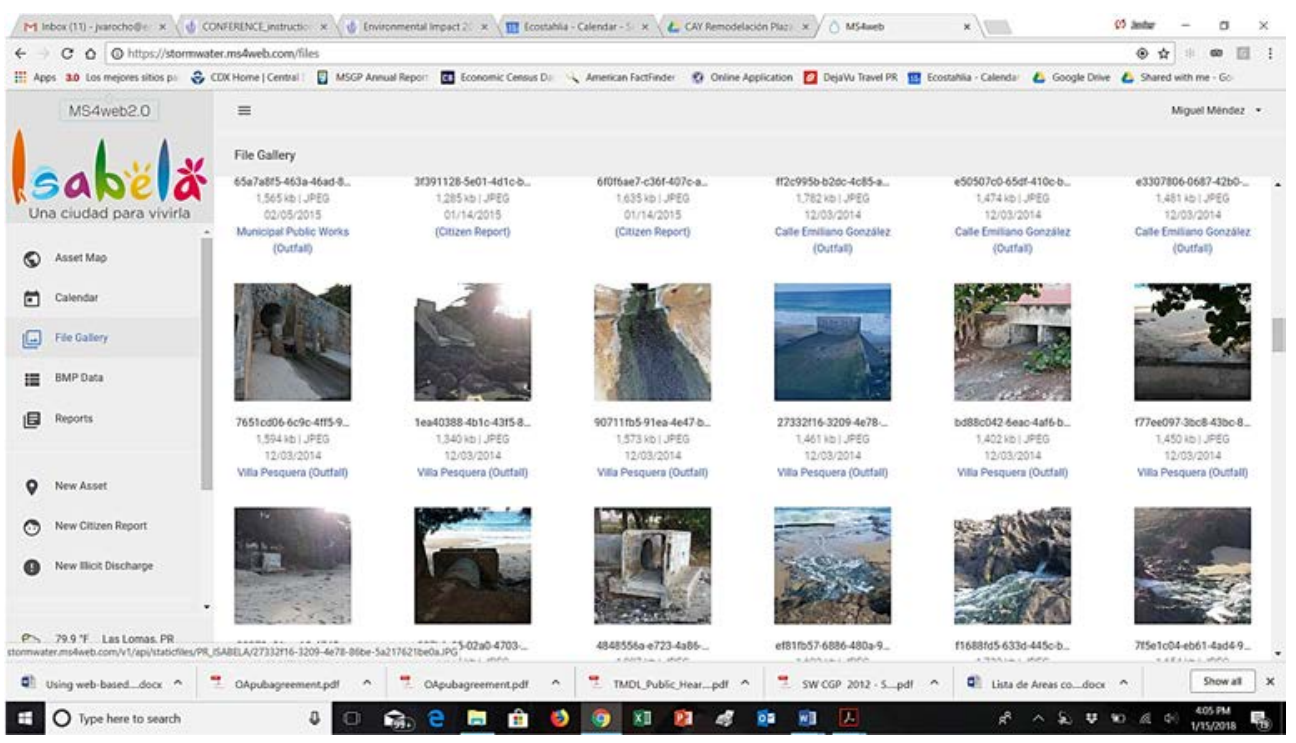

Figure 4: Image of a screenshot from the MS4Web ${ }^{\text {TM }}$ Interphase showing the gallery of outfalls and discharge points for reference.

compared to the $\$ 400.00$, the fixed cost of one FTE using the MS4Web ${ }^{\text {TM }}$ Permit Manager. The cost associated with the FTE includes transportation expenses, salaries, benefits, materials, and gasoline for a 4-hour event, which is the basic procedure, used by most municipalities. The cost savings using a contractor and the web-based tool is $\$ 154.00$. The fixed-cost using a contractor is based on an 8-hour event, which is the common practice in the market. For most municipalities working in the implementation of the NPDES-MS4 regulation, the use of a Full-Time Employee is limited as many of the resources share other responsibilities related to the compliance of environmental regulation. According to one of the authors working with different local governments, the managers of an environmental compliance office for a small city find it very difficult to allocate human and financial resources to conduct inspections out of the urban area due to an increase in the costs per inspection. The costs associated with performing an inspection is relatively more economical if the employees and contractor drive less than 30 miles from the urban center (personal communication) [10]. Other variables also play an important role in determining the costs of an inspection event, as the regulation states that dry-weather inspections and water quality monitoring of stormwater discharges can only be performed under certain conditions. For example, dry-weather inspections can be conducted after 48 hours of a significant rain event ( $>$ 2inches of water) or stormwater monitoring can be performed in the first 30 minutes after a rain event starts [11].

Table 1: Comparison of daily costs inspections per city vs. cost using the MS4Web ${ }^{\mathrm{TM}}$.

\begin{tabular}{|c|c|c|}
\hline Average daily cost city & Average daily MS4Web & Difference \\
\hline$\$ 554.00^{*}$ & $\$ 400.00^{* *}$ & $\$ 154.00$ \\
\hline
\end{tabular}

Note: The prices for both alternatives include salaries, per-diem, transportation, and equipment. *Average price for an $8 \mathrm{hrs} /$ day inspection event. ** Average price for an $8 \mathrm{hrs} /$ day inspection event. 


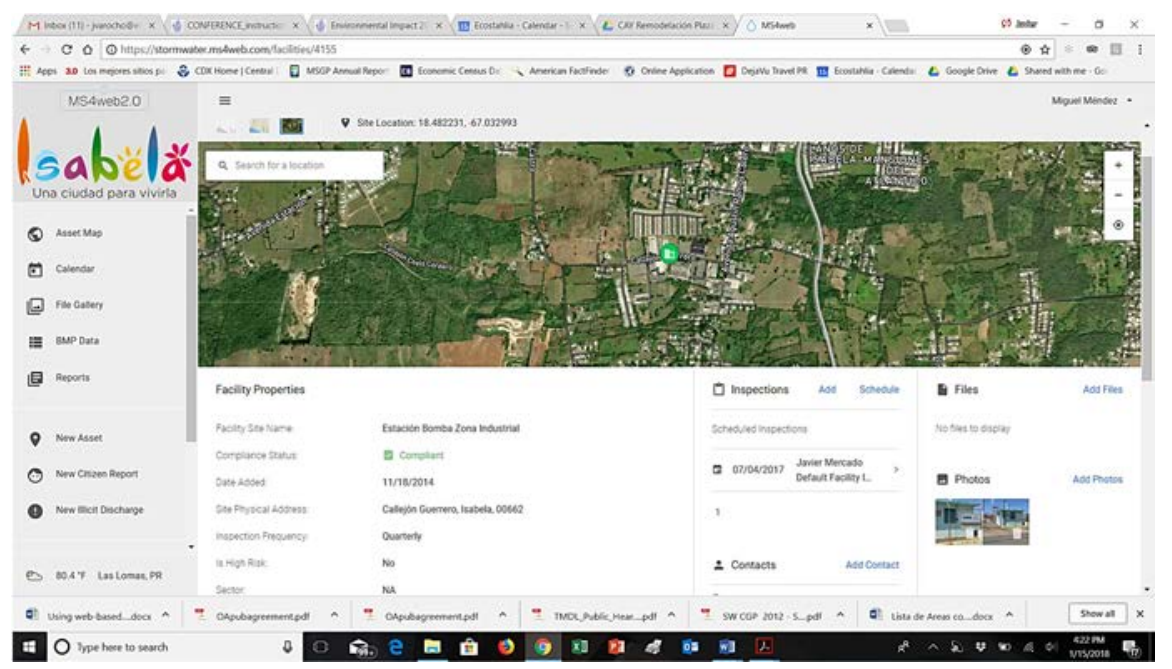

Figure 5: Image of a screenshot from the MS4Web ${ }^{\mathrm{TM}}$ Interphase showing a report summary during a dry-weather monitoring of an outfall.

\section{CONCLUSIONS}

Environmental monitoring is a key element to understand whether the quality of our environment is improving or not. The information gathered through environmental monitoring is important to the federal, state and municipal decision makers to address their water quality issues. The monitoring and permit manager web tools can help with forecast, modeling and can help to manage the problems, support the decision-making and for preparing corrective and preventive plans. This new approach provides municipal managers with a unique opportunity to collect data across multiple MS4s that affect an isolated area since Puerto Rico is an island. Over time, both software users, providers, and regulators will have data sets that will allow them to provide analysis to the municipalities of what they are doing right and where they need to improve based not only on what they are doing but on what other municipalities surrounding them are doing. The fact that MS4web is a GIS application will allow them to add additional layers of data collected during the inspections to draw an even more sophisticated analysis of how Puerto Rico is doing in overall environmental compliance. The benefit of these new Internet-based applications extends beyond the dollar savings of each municipality and becomes a data management tool for all Puerto Rico and leads the municipalities into the future. And the future is electronic data reporting directly to the EPA to provide even larger data sets within EPA regions and eventually across the entire continental United States [12].

\section{REFERENCES}

[1] Anne Arundel County, Maryland. Department of Public works. www.aacounty.org/ departments/public-works/wprp/npdes-ms4-permit. Accessed on: 7 Oct. 2017.

[2] The United States Environmental Protection Agency (USEPA). EPA Region 2 Small MS4 General Permit. www3.epa.gov/region02/water/npdes/permits/pdfs/2016_ Final_NPDES_Small_MS4_General_Permit_(signed).pdf. Accessed on: 7 Oct. 2017. 
[3] The Interamerican University of Ponce, Chapter 2 Puerto Rico: The Development Model and Environment. http://ponce.inter.edu/cai/tesis/arios/cap2.html. Accessed on: 7 Oct. 2017.

[4] The United States Department of Justice, Archives, Overview: Puerto Rico and the Virgin Islands. www.justice.gov/archive/ndic/pubs3/3950/overview.htm. Accessed on: 9 Nov. 2017.

[5] Census, Puerto Rico 2010. www.census.gov/prod/cen2010/cph-2-53.pdf. Accessed on: 9 Nov 2017.

[6] The Whitehouse. www.whitehouse.gov/omb/fedreg_gpea2. Accessed on: 10 Nov. 2017.

[7] Bright Hub, Internet, Web Development, Careers Web Site. www.brighthub.com/ internet/web-development/articles/25776.aspx. Accessed on: 10 Nov. 2017.

[8] PR.GOV, Presupuesto Aprobado 2015-2016. www2.pr.gov/presupuestos/Presupuesto 2015-2016/PresupuestosAgencias/suppdocs/baselegal/016/151-2004.pdf. Accessed on: 11 Nov. 2017.

[9] The University of Kentucky, History of Mobile Applications. www.uky.edu/ jclark/ mas490apps/History\%20of\%20Mobile\%20Apps.pdf. Accessed on: 12 Nov. 2017.

[10] The MS4Web Permit Manager. www.ms4web.com/about.html. Accessed on: 12 Nov. 2017.

[11] The MS4Front Permit Manager. www.ms4front.com/. Accessed on: 12 Nov. 2017.

[12] Rivera, G.P.L., Personal communication, 13 Nov. 2017, Director Office of Environmental Affairs, Autonomous Municipality of Caguas, PR.

[13] The United States Environmental Protection Agency (USEPA). www3.epa.gov/ npdes/pubs/idde chapter-1.pdf.

[14] The United States Environmental Protection Agency (USEPA). Compliance, Final National Pollution Discharge Elimination System (NPDES), Electronic Reporting Rule. $\quad$ www.epa.gov/compliance/final-national-pollutant-discharge-eliminationsystem-npdes-electronic-reporting-rule. Accessed on: 10 Nov. 2017. 